\title{
PREVALENCE AND FACTORS ASSOCIATED TO HOUSEHOLD FOOD INSECURITY DURING COVID-19 OUTBREAK
}

\author{
Dian Luthfiana Sufyan, ${ }^{1 \text { * }}$ Muh. Nur Hasan Syah, ${ }^{1}$ Nurbaya ${ }^{2}$ \\ ${ }^{1}$ Nutrition Study Program, Faculty of Health Science, Universitas Pembangunan Nasional Veteran Jakarta, \\ 16515, Indonesia \\ ${ }^{2}$ Health Polytechnic of Mamuju, West Sulawesi, 60172, Indonesia
}

\begin{abstract}
COVID-19 outbreak added unprecedented threatens to the food system worldwide. The enactment of social restriction regulation by several provinces in Indonesia may give an impact to household food security. Economical access to food might be compromised since the application of work from home policy, particularly for those who earn income from informal sector jobs. This study aims to determine the proportion of household food insecurity during the COVID-19 pandemic, identify the associated factors, and the strongest predictor of household food insecurity. This cross-sectional study design was carried out in Java and Sulawesi. A Self-administered Google Form Questionnaire was filled out by 191 women of reproductive age as the household food gatekeeper. Household food insecurity was evaluated using the Food Insecurity Experience Scale (FIES) Questionnaire by FAO that consisted of eight gradual questions. Data analysis was performed using statistical software for univariate, bivariate (chi-square), and multivariate (logistic regression). The proportion of food insecurity in the study was $29.8 \%$, encompassed $19.9 \%$ mild food insecure, $7.3 \%$ moderate food insecure, and $2.6 \%$ severe food insecure. Food insecurity was significantly associated with place of residence, family income, and education. Living in urban areas was among the robust predictor of household food insecurity (OR 5.59, CI 95\%), meaning living in urban was a risk factor of household food insecurity during the COVID-19 pandemic. Urban living was highly dependent on routine salary since they might not occupy with some sort of alternative source for income like in the rural areas, however, there was income reduction during the crisis. Food insecurity might be a sting in the tail of the COVID-19 pandemic, food policy regarding this matter is urgently required.
\end{abstract}

Keywords: COVID-19, food insecurity, Indonesia

\begin{abstract}
ABSTRAK
Pandemi COVID-19 telah memberikan ancaman kepada ketahanan pangan secara global. Pemberlakuan Pembatasan Sosial Berskala Besar (PSBB) oleh sejumlah provinsi dapat menyebabkan kerawanan pangan. Akses pangan secara ekonomi dapat terganggu karena penerapan regulasi bekerja dari rumah, terutama bagi masyarakat yang mencari nafkah pada sektor informal. Studi ini bertujuan untuk mengetahui prevalensi kerawanan pangan tingkat rumah tangga selama terjadinya pandemi serta mengidentifikasi faktor determinan kerawanan pangan. Studi potong lintang ini dilakukan di Pulau Jawa dan Sulawesi kepada 191 wanita usia subur. Pengumpulan data menggunakan kuesioner Food Insecurity Experience Scale (FIES) melalui pengisian mandiri. Analisis data dilakukan dengan software statistik untuk menyajikan data univariat, bivariat (chi-square) dan multivariat (regresi logistik). Proporsi rumah tangga rawan pangan sebesar $29.8 \%$, terdiri dari $19.9 \%$ rawan pangan ringan, $7.3 \%$ rawan pangan sedang dan $2.6 \%$ rawan pangan berat. Kerawanan pangan berhubungan secara bermakna dengan tempat tinggal, pendapatan keluarga, dan pendidikan. Bertempat tinggal di wilayah perkotaan menjadi prediktor terkuat dari kerawanan pangan (OR 5.59, CI 95\%), hal ini dapat dikarenakan ketergantungan pada pendapatan rutin tanpa adanya sumber alternatif lain di masa pandemi. Terdapat resiko efek berkelanjutan meski pandemi COVID-19 telah berakhir, sehingga kebijakan pangan sangat diperlukan.
\end{abstract}

Keywords: COVID-19, Kerawanan pangan, Indonesia

Correspondece Address: Dian Luthfiana Sufyan, Nutrition Study Program, Faculty of Health Science, Universitas Pembangunan

Nasional Veteran Jakarta, E-mail: dian.sufyan@upnvj.ac.id 


\section{Introduction}

World Health Organization has declared COVID-19 as a Public Health Emergency of International Concern since early 2020. ${ }^{1}$ This formal statement then responded by a number of countries by implementing lockdowns, travel restrictions and social distancing in order to control the virus transmission. ${ }^{2}$ The policies aforementioned were also applied in Indonesia with less restrictive lockdown, known as large-scale social restriction (Pembatasan Sosial Berskala Besar) or PSBB. ${ }^{3}$ The implementation of PSBB involves the closure of the workplace, worship place and school, and to be conducted at home. ${ }^{3}$ The transition caused by the adaptation to this new habit brings dramatic changes to the various sectors including the food system. ${ }^{2}$ United Nation mention that the outbreak gives impact to the second goal of SDGs, when the COVID-19 crisis adds the threats to the food system by adding more than 130 million people at risk of suffering hunger. ${ }^{4}$ However, there is preceded condition of hunger that may involve larger number of people at risk, which is food insecurity that best describes the iceberg phenomena. ${ }^{5}$

Food insecurity is a condition of limited or uncertain availability of nutritious and safe food as social determinants of health that could affect the vulnerable group at the household level such as women and children. ${ }^{6}$ While food security as defined by Indonesia Law No.18 is the condition of an individual or a household food fulfillment that is reflected by sufficient food availability either quantitatively or qualitatively, safe, diverse, nutritious, affordable and not contradicted to religion, belief and culture, to be able to live a healthy, active and productive life in a sustainable manner. ${ }^{7}$ The Global Hunger Index (GHI) 2020 noted Indonesia ranked $70^{\text {th }}$ out of 107 countries and had a moderate level of hunger with GHI score of 19.1. ${ }^{8}$ Indonesia Statistics noted a declining prevalence of individual food insecurity in 2017 to 2020 (8.66\% and $5.12 \%$ respectively). ${ }^{9}$ However, a secondary analysis of the 2015 nationwide household and expenditure survey (SUSENAS) indicated $20.8 \%$ of household food insecurity. ${ }^{10}$ Moreover, the 2019 Indonesia Food Insecurity Atlas identify six provinces (Bangka Belitung, West Kalimantan, Maluku, East Nusa Tenggara, West Papua and Papua) with a low score of food security index that indicates a high ratio of consumption to net production per capita, high prevalence of stunted under-five children, and a high proportion of poor people. ${ }^{11}$

At the time of the COVID-19 pandemic, Indonesian household consumption is predicted to decline by $8.29 \%{ }^{12}$ Food insecurity is the barrier to sustainable development, since it leads an individual to be less productive, more susceptible to disease and earn less. ${ }^{13}$ As the vulnerable age group of this condition, the Indonesia Basic Health Survey 2018 estimated 17.7\% under-five children are underweight, $30.8 \%$ are stunted, and $10.2 \%$ are wasted. ${ }^{14}$ At the same time, this malnutrition problem increases vulnerability to COVID-19. ${ }^{15}$ Food security has four pillars i.e. 
availability, access, utilization, and stability. Food availability corresponds to the food supply. Access refers to how households reach the food, both economic and physical access and utilization related to dietary quality. The fourth pillar is these pillars should stable, which means when one of these pillars is not fulfilled, it will potentially cause food insecurity. ${ }^{16}$ Economic and physical access to food might be impaired during the pandemic, since the application of work from home policy.

The economic disruptions during the COVID-19 pandemic and it's negative impacts on households' food security are far more likely to impact the poor and vulnerable groups such as market dependant rural households and low-income urban households. ${ }^{17}$ Income decreases, especially for those who earn daily wages from the informal sector jobs. A survey stated that fiftyfive percent of men and 57 percent of women reported no longer working due to the pandemic. Job loss has affected all sectors and makes them more vulnerable to suffer from food insecurity. ${ }^{18}$ This study is pivotal to be undertaken since food security positively impacts on education, health, economics and social development. Additionally, food insecurity is an unprecedented tail of the COVID-19 outbreak, it is better to identify the determinants for fast recovery of food system through evidence-based program development and policy advocation. This study aimed to determine the proportion of household food insecurity during the COVID-19 pandemic, identify the associated factors, and identify the robust predictor of household food insecurity.

\section{Method}

This cross-sectional study design was conducted in Java and Sulawesi (both applied largescale social restriction policy) from May to August 2020 using a Self-administered Google Form Questionnaire. The questionnaire was broadcasted for two months long through the online platform, such as Whatsapp, Instagram and Facebook to obtain participants, who were married women aged 17-49 years old. In order to reassure the eligible participants, several filtered questions were applied at the beginning of the questionnaire that asked about age, marital status and whether they in charge of food provision at home. Those who were uneligible would be discontinued. In total, there were 191 women who were aged 17-49 years old, married, and able to serve food for the family (food gatekeeper).

The questionnaire consisted of two sections, which were demographic characteristics (age, place of residence, type of family, monthly income, education and occupation, and under-five children) and household food insecurity. All data were obtained online with a validated questionnaire. Demographic characteristics were considered as an independent variable, while food insecurity was considered as a dependent variable. The age of the participants was represented by two categories: younger than and equal to 30 years old and older than 30 years old. Place of residence classified as urban and rural, based on Indonesia Statistics classification. ${ }^{19}$ Type of 
family categorized as nuclear and extended family. Family monthly income is grouped as more than equal to 5 million IDR and less than 5 million IDR. Educational attainment is classified as high school and higher education graduates. Working status was grouped as not working and working. Household food insecurity was assessed using the Food Insecurity Experience Scale (FIES) Questionnaire by FAO that consisted of eight gradual questions. The questionnaire asked about the family experience in the past one month whether they worried to not have enough food, inability to eat healthy food, only have few kinds of food, skipping mealtime, compromising the food portion, ran out of food, hungry with no food and skip eating the whole day all due to lack of money. ${ }^{20}$ The scoring system for food insecurity variable was as followed: food secure (score 0 ), mild food insecure (score 1), moderate food insecure (score 2 to 5), and severe food insecure (score 5 to 8$)^{20}$.

Data were analyzed using statistical software for univariate, bivariate, and multivariate with CI 95\%. Univariate analysis to describe the frequencies and proportion of characteristics of the sample. Bivariate analysis was conducted using chi-square to identify any potential associations between variables and household food insecurity. Further, multivariate analysis was performed using logistics regression to assess crude and adjusted odds ratio. Variables that show significant values less than 0.05 are treated as covariates on the analysis.

This research was ethically approved and declared by the Health Research Ethics Committee of the Universitas Pembangunan Nasional Veteran Jakarta (approval number 2617/VI/2020/KEPK). Informed consent was obtained from each participant prior to data collection.

\section{Results}

A total of 210 subjects were assessed. From those assessed, 19 were excluded with detail of irrelevant responses to food insecurity questions. The final analytical sample involving 191 respondents. In our analysis, out of 191 women, $29.8 \%$ of them were food insecure (95\% CI). This food insecurity can be further categorized as mild food insecure, moderate food insecure, and severe food insecure (the proportion were $19.9 \%, 7.3 \%$ and 2.6 respectively). Table 1 shows the subject's characteristics based on several variables. Most respondents were aged less than 30 years, lived in an urban area with a nuclear family, had a monthly income higher than 5 million IDR, were higher education graduates, worked as a civil servants, and had under-five childre 
Table 1. Subject characteristics

\begin{tabular}{lcc}
\hline Explanatory variables & $\mathbf{n}$ & $\mathbf{\%}$ \\
\hline Age & & \\
$\leq 30$ & 97 & 50.8 \\
$\quad>30$ & 94 & 49.2 \\
Place of residence & 161 & 84.3 \\
$\quad$ Urban & 30 & 15.7 \\
$\quad$ Rural & & \\
Type of family & 126 & 66 \\
$\quad$ Nuclear & 65 & 34 \\
$\quad$ Extended & & \\
Family monthly income & 86 & 45 \\
$\quad<5$ million & 105 & 55 \\
$\quad \geq 5$ million & & \\
$\quad$ Education & 29 & 15.2 \\
$\quad$ Primary and high school & 162 & 84.8 \\
$\quad$ Higher education & & \\
Working status & 50 & 26.2 \\
$\quad$ Not working & 141 & 73.8 \\
$\quad$ Working & & \\
Having under-five children & 130 & 68.1 \\
$\quad$ Yes & 61 & 31.9 \\
$\quad$ No & & \\
$\quad$ Food security & 134 & 70.2 \\
$\quad$ Food secure & 57 & 29.8 \\
Food insecure & & \\
$\quad$ Mild food secure & 38 & 19.9 \\
$\quad$ Moderate food insecure & 14 & 2.6 \\
$\quad$ Severe food insecure & 5 &
\end{tabular}

Table 2 below, shaw that present a cross-tabulation between food insecurity and all explanatory variables.

Table 2. Proportion of food insecurity by characteristics

\begin{tabular}{|c|c|c|c|c|c|}
\hline \multirow[b]{2}{*}{ Variable } & \multicolumn{4}{|c|}{ Food insecurity } & \multirow[b]{2}{*}{$\boldsymbol{P}$} \\
\hline & $\frac{\text { Yes }}{57}$ & $\frac{\%}{29.8}$ & $\frac{\text { No }}{134}$ & $\frac{\%}{70.2}$ & \\
\hline \multicolumn{6}{|l|}{ Age } \\
\hline$\leq 30$ & 33 & 34.0 & 64 & 66.0 & \multirow[t]{2}{*}{0.21} \\
\hline$>30$ & 24 & 25.5 & 70 & 74.5 & \\
\hline \multicolumn{6}{|l|}{ Place of residence } \\
\hline Urban & 38 & 23.6 & 123 & 76.4 & \multirow[t]{2}{*}{$<0.01$} \\
\hline Rural & 19 & 63.3 & 11 & 36.7 & \\
\hline \multicolumn{6}{|l|}{ Type of family } \\
\hline Nuclear & 35 & 27.8 & 91 & 72.2 & \multirow[t]{2}{*}{0.24} \\
\hline Extended & 22 & 33.8 & 43 & 66.2 & \\
\hline \multicolumn{6}{|l|}{ Family monthly income } \\
\hline$<5$ million & 44 & 51.2 & 42 & 48.8 & \multirow[t]{2}{*}{$<0.01$} \\
\hline$\geq 5$ million & 13 & 12.4 & 92 & 87.6 & \\
\hline \multicolumn{6}{|l|}{ Education } \\
\hline Primary and high school & 17 & 56.8 & 12 & 41.4 & \multirow[t]{2}{*}{$<0.01$} \\
\hline Higher education & 40 & 29.8 & 122 & 75.3 & \\
\hline \multicolumn{6}{|l|}{ Working status } \\
\hline Not working & 16 & 32 & 34 & 68 & \multirow[t]{2}{*}{0.69} \\
\hline Working & 41 & 29.1 & 100 & 70.9 & \\
\hline \multicolumn{6}{|l|}{ Having under-five child } \\
\hline Yes & 40 & 30.8 & 90 & 69.2 & \multirow[t]{2}{*}{0.41} \\
\hline No & 17 & 27.9 & 44 & 72.1 & \\
\hline
\end{tabular}


Tabel 2 showed a significant association between place of residence, family monthly income, and education with food insecurity $(P<0.01$ CI 95\%). No significant association was found between age, type of family, under-five children availability on family with food insecurity.

Independent variables that were significant associated with food insecurity based on bivariate analysis, were treated as covariates. Additionally, the type of family was also assessed on multivariate analysis since the size of the family may influence the food distribution at home and affect the household food security.

In logistics regression (Table 3), place of residence, family monthly income, and education were significantly associated with food insecurity. The odds for having food insecurity is about 5.59 times higher on those who lived in urban compared to rural. Those who earned income less than 5 million IDR have chance of 0.13 times lower to suffer food insecurity as compared to those who earned more. Households with women food gatekeeper who attained primary and high school education had 0.23 times lower chance to suffer food insecurity as compared to those who were higher education graduates. Lower family income and educational attainment were found to be protective factors toward food insecurity. No significant association was found on logistics regression of type of family with food insecurity.

Table 3. Logistics regression

\begin{tabular}{|c|c|c|}
\hline Variable & OR (CI 95\%) & $P$ \\
\hline \multicolumn{3}{|l|}{ Place of residence } \\
\hline Urban & $5.59(2.44-12.78)$ & $<0.01$ \\
\hline Rural & - & \\
\hline \multicolumn{3}{|l|}{ Family monthly income } \\
\hline$<5$ million & $0.13(0.06-0.27)$ & $<0.01$ \\
\hline$\geq 5$ million & - & \\
\hline \multicolumn{3}{|l|}{ Education } \\
\hline Primary and high school & $0.23(0.10-0.52)$ & $<0.01$ \\
\hline Higher education & - & \\
\hline \multicolumn{3}{|l|}{ Type of family } \\
\hline Nuclear & $1.33(0.28-0.32)$ & 0.38 \\
\hline Extended & - & 0.38 \\
\hline
\end{tabular}

\section{Discussion}

No evidence showed that COVID-19 is foodborne, however, the crisis is resulting in a major impact on food security through several dynamics. ${ }^{21}$ The High-Level Panel of Experts on Food Security and Nutrition depicted seven dynamics caused by COVID-19 outbreak that affect food security. ${ }^{15}$ First is the disruption of food supply chains in the form of declining demand for perishable foods and export-import borders restriction. This dynamic affects food availability, mainly for fruits, vegetables and animal protein since people prefer to stock foods with a longer shelf life that mostly compromised the nutrition value. ${ }^{22}$ Second is the economic recession that is compounded with income losses. The reduction of regular income and numbers of employees even 
laid off affect family purchasing power and economical access to food. In order to cope in such situation, households that even already vulnerable prior COVID-19 outbreak will compromise their eating pattern quantitatively (reducing portion) and qualitatively (compromise diversity) ${ }^{23}$ Third is social inequities, the 2020 national online survey undertaken by National Commission on Violence Against Women revealed the effects of the outbreak on women's life, among them are the increase in domestic burden, stress, and domestic violence. ${ }^{24}$ SMERU Research Institute reported that COVID-19 has lowered women's labor force involvement since it hits informal sector jobs that mainly engage female workers. Subsequently, there is a decrease in family income, while at the same time women are also the household food gatekeeper. ${ }^{25}$ Fourth is disruption on social protection program, as the implementation of PSBB, the government expanse various social protection program for vulnerable families like never before, such as the increased allowance for conditional cash transfers, food assistance, pre-employment card, social assistance, unconditional cash transfer, electricity subsidy and logistics. ${ }^{26}$ However, at the end of 2020, Indonesia Corruption Eradication Commission (KPK) revealed social assistance bribery that involved several officials from Ministry of Social Affairs, leaving a significant loss for Indonesia and a deepened dissapointment. ${ }^{27}$ Fifth is food environment alteration. During PSBB period, Indonesia government still allow food retails to operate, however in the beginning of the policy announcement, panic buying was done by people especially in the big city like Jakarta. ${ }^{28}$ This kind of circumstance affects the whole food environment and food prices. In contrast, some people restrict themself to go further for shopping and prefer the supermarket nearby, as they avoid potential disease transmission. ${ }^{15}$ The sixth is food price increases when government regulates the closure of restaurants and market. During the crisis, households with limited economical access prefer staple food that are more filling, yet low in nutrition value, as food prices are conversely linked with nutrition value. ${ }^{29}$ The seventh is changes in food production due to the closure of the workplace.

The proportion of food-insecure households in our analysis was $29.8 \%$ (95\% CI). This consisted of $19.9 \%$ mild food insecure which means a family that underwent uncertainty regarding the ability to obtain food. The proportion of $7.3 \%$ was moderate food insecure which means a family was compromising food quality, variety, even reducing food quantity and skipping meals. This can be caused by insufficient money to afford an adequate quality of food. The last one was severe food insecurity $(2.6 \%)$ which means that a family had no food for a day or more. This can be resulted from running out of food ${ }^{30}$ Secondary data analysis of the 2015 nationwide household socioeconomic and expenditure survey (Survei Sosial Ekonomi Nasional) indicated 20.8\% of the household were in the food insecure category ${ }^{10}$, lesser than what is found in this study. This can be attributed to the specific circumstances during the COVID-19 outbreak, where work from home policy was applied and may impact economical access to food. ${ }^{25}$ 
The bivariate analysis showed that family size had no association with household food security. However, a Nigeria study noted that the larger the family size, then the lesser food will available for each person within the household. ${ }^{31}$ Regarding the association between place of residence and food security on logistics regression, a household in the urban area tend to be more food insecure than those in a rural area, which is contrary with secondary data analysis of the socioeconomic survey, with a point of view was attributed to the wide gap in household income between both areas. Also, the urban area was mostly economically developed rather than urban area ${ }^{10,25}$. However, our study found an inverse result, this can be attributed to urban society that does not have any alternative source of income other than routine work. ${ }^{32}$ No significant association was found between the type of family with food security using logistics regression. However, it showed a significant association in the bivariate analysis. Living with a bigger family size was more likely that the dependency ratio is high. ${ }^{10}$ Significant association was also found between education and food security. Higher education made persons had plenty of choices to work and had better income. ${ }^{10,32}$ Inverse results also found on the association between family income, education attainment and household food insecurity. The possible explanation for these circumstances can be attributed to the income reduction during the outbreak. Not only because the income reduction, but also those who earn more than 5 million, possibly distributed the income to some credit purchase, so that it may be compounded the food provisioning.

Food insecurity may affect individual nutritional status as it resulted in micronutrient deficiency, starvation, morbidity, and even mortality. ${ }^{33,34}$ Four pillars constructed food security, which are food availability, food access, food utility, and food stability. Food availability means the food is available and adequate to be consumed. Food access refers to household affordability to physical access and economical access to food. Food utility means that households or individuals can utilize food as it should be with no pathophysiological condition. Food stability means that households or individuals have access, utilize, and available food anytime without any restriction. ${ }^{35}$ Finally, food policies should be advocated. For instance the implementation of targeted social protection by providing adequate food aid and food assistance, ensuring special protection for vulnerable groups, maintaining the food prices, discourage food export and develop a campaign to educate people on healthy eating by consuming localized and affordable foods.

\section{Conclusion}

A high prevalence of household food insecurity is revealed during the COVID-19 outbreak (29.8\%). Several factors associated with household food insecurity are the place of residence, family income, and educational attainment. Family income and living in an urban area is found to be the risk factor of household food insecurity. The possible explanation for this finding is that the 
urban family may do not have an alternative source of income as compare to rural families to be able to cope with the changes in the food system during the pandemic.

\section{Acknowledgment}

We would like to thank all the participants who took part in this research. We also thank the LPPM of Universitas Pembangunan Nasional Veteran Jakarta for administratively supporting the research.

\section{Funding}

This research received no funding.

\section{Conflict of Interest}

All authors declared no potential conflicts of interest with respect to the research, authorship and/or publication of this article.

\section{Reference}

1. World Health Organization (WHO). Timeline: WHO's COVID-19 response. 2020. Available from: https://www.who.int/news-room/detail/29-06-2020-covidtimeline [Accessed 29th May 2021].

2. Committee for the Coordination of Statistical Activities (CCSA). How COVID-19 is changing the world: A statistical perspective. Vol II. 2020. Available from: https://unstats.un.org/unsd/ccsa [Accessed 28th May 2021].

3. Udmale P, Pal I, Szabo S, Pramanik M, Large A. Global food security in the context of COVID-19: A scenario-based exploratory analysis. Prog Disaster Sci. 2020;7(3):1-7.

4. United Nations. Goal 2: Zero hunger - United Nations sustainable development. 2018. Available from: https://www.un.org/sustainabledevelopment/hunger [Accessed 29th May 2021].

5. The Lancet Global Health. Food insecurity will be the sting in the tail of COVID-19. Lancet Glob Heal. 2020;8(6):e737.

6. Patterson JG, Russomanno J, Teferra AA, Jabson Tree JM. Disparities in food insecurity at the intersection of race and sexual orientation: A population-based study of adult women in the United States. BMC Public Health. 2020;20 (1155): 1-11.

7. Republik Indonesia. Undang-Undang Republik Indonesia nomor 18 tahun 2021 Tentang Pangan. 2012. Available from: https://peraturan.bpk.go.id/Home/Details/39100 [Accessed 29th May 2021]. 
8. Global Hunger Index. Global hunger index 2020: Indonesia. 2020. Available from: https://www.globalhungerindex.org/indonesia.html [Accessed 15th May 2021].

9. Badan Pusat Statistik (BPS). Prevalensi penduduk dengan kerawanan pangan sedang atau berat, berdasarkan pada skala pengalaman kerawanan pangan (persen). Available from: https://www.bps.go.id/indicator [Accessed 20th May 2021].

10. Amrullah ER, Ishida A, Pullaila A, Rusyiana A. Who suffers from food insecurity in Indonesia? Int J Soc Econ. 2019;46(10):1186-1197.

11. Kementerian Pertanian. Indeks ketahanan pangan indonesia 2019 (Food security index of Indonesia 2019). 2020. Available from: http://bkp.pertanian.go.id/storage/app/media [Accessed 21st May 2021].

12. Amanta F, Aprilianti I. Indonesian food trade policy during COVID-19. Center for Indonesian Policies Studies. 2020. Available from: https://repository.cips-indonesia.org [Accessed 21st May 2021].

13. United Nations (UN). Why it matters: No hunger. 2020. https://www.un.org/sustainabledevelopment [Accessed 21st May 2021].

14. Kementerian Kesehatan RI. Riset Kesehatan Dasar (Riskesdas) 2018. 2018. Lembaga Penerbitan dan Pengembangan Kementerian Kesehatan Republik Indonesia (Kemenkes RI), Jakarta.

15. High Level Panel of Experts (HLPE). Impacts of COVID-19 on food security and nutrition: developing effective policy responses to address the hunger and malnutrition pandemic. 2020. Food and Agriculture Organization, Rome.

16. Devereux S, Béné C, Hoddinott J. Conceptualising COVID-19's impacts on household food security. Food Secur. 2020;12(4):769-772.

17. World Food Programme. COVID-19: economic and food security implications - Indonesia. 2020;(May):1-12.

18. United Nations Children's Fund (UNICEF). COVID-19 and children in Indonesia. UNICEF. 2020. Available from: https://www.unicef.org/indonesia/ [Accessed 11th May 2021].

19. Badan Pusat Statistik Indonesia. Peraturan Kepala Badan Pusat Statistik nomor 37 tahun 2010 tentang klasifikasi perkotaan dan perdesaan di Indonesia. 2010. Badan Pusat Statisistik Republik Indonesia, Jakarta.

20. Cafiero C, Nord M, Viviani S, et al. Methods for estimating comparable prevalence rates of food insecurity experienced by adults throughout the world. 2016. Available from: http://www.fao.org/3/a-i4830e.pdf [Accessed 11th May 2021].

21. International Comission on Microbiological Specifications for Foods. ICMSF opinion on SARS-CoV-2 and its relationship to food safety. 2020. Available from: https://www.foodauthority.nsw.gov.au/sites [Accessed 11th May 2021]. 
22. Barrett CB. Actions now can curb food systems fallout from COVID-19. Nat Food. 2020;1(6):319-320.

23. Rozaki Z. COVID-19, agriculture, and food security in Indonesia. Reviews in Agricultural Science. 2020;8(4):243-260

24. Qibtiyah A, Ratnawati R, Hodijah SN, Kartika DA, Yulianti M. Kajian dinamika perubahan di dalam rumah tangga selama COVID-19 di 34 provinsi di Indonesia. 2020. Available from: https://komnasperempuan.go.id/uploadedFiles [Accessed 11th May 2021].

25. Rahman MA, Zuhdi A, Kusuma D, Arfyanto H. Situasi ketenagakerjaan di lapangan usaha yang terdampak pandemi COVID-19. 2020. SMERU Institute, Jakarta.

26. Arif S, Isdijoso W, Fatah AR, Tamyis AR. Strategic review of food security and nutrition in Indonesia. 2020. SMERU Institute, Jakarta.

27. Komisi Pemberantasan Korupsi. KPK tahan Menteri Sosial terkait perkara dugaan suap pengadaan bansos COVID-19. Siaran Pers. 2020. Available from: https://www.kpk.go.id/id/berita/siaran-pers/1986 [Accessed 1st June 2021].

28. World Food Programme. Indonesia food price update - March 2020 focus: Effect of COVID19 outbreak on food prices. 2020. WFP, Jakarta.

29. Drewnowski A, Specter S. Poverty and obesity: the role of energy density and energy cost. Am J Clin Nutr. 2004;79(1):6-16.

30. FAO, IFAD, UNICEF, WFP and W. The State of food security and nutrition in the world 2018.

31. Olayemi AO. Effects of Family Size on Household Food Security in Osun State, Nigeria. Asian J Agric Rural Dev. 2012;2(22):136-141.

32. Mutiah SA, Istiqomah I. Determinants of household food security in urban areas. Jejak. 2017;10(1):103-120.

33. World Food Program. Peta ketahanan dan kerentanan pangan indonesia a food security and vulnerability atlas of Indonesia. Dewan Ketahanan Pangan, Depertemen Pertanian RI and WFP; 2010.

34. Kementerian Kesehatan RI. Laporan Provinsi DKI Jakarta Riskesdas 2018. Lembaga Penerbitan Badan Penelitian dan Pengembangan Kesehatan; 2019.

35. Singh A, Singh A, Ram F. Household food insecurity and nutritional status of children and women in Nepal. Food Nutr Bull. 2014;35(1):3-11. 